\title{
UN ENCUENTRO CON LAS FORMAS VIVIENTES DEL DISCURSO DE DAVI KOPENAWA
}

An encounter with scentient beings from Davi Kopenawa's discourse

\author{
ÁNGELA PARGA-LEÓN \\ Universidad de Los Lagos (Chile) \\ angela.parga@ulagos.cl
}

Resumen

Esta exposición intenta comprender las formas culturales de comunicación y fijación mnémica en una narración específica que Davi Kopenawa, chamán Yanomami, expone al antropólogo Bruce Albert ${ }^{1}$, en virtud de los modos de existencia amazónicos, refiriéndose en particular a la intensidad de los espíritus selváticos y a la experiencia chamánica con los mundos espirituales. En el contexto de una extensión vegetal dispersa y sobresaliente, afirmamos una sociabilidad cotidiana en el marco de una "ética respetuosa o amorosa" entre todas las formas de vida, expresada estéticamente en formas significantes y transportadoras de emociones desarrolladas por la cosmología amazónica. Para ello utilizamos las nociones que Aby Warburg emplea en su estudio de la cultura de las imágenes, en tanto curso por el que estas pueden entenderse como organismos vivientes susceptibles a transformación, preservando su propia biología en la trasmisión codificada de la memoria.

Palabras clave: Memoria; supervivencia (Nachleben); fórmula de pathos (pathosformeln).

Abstract

This exhibition tries to understand the cultural forms of communication and mnemic fixation in a specific narrative that Davi Kopenawa, Yanomami shaman, exposes to the anthropologist Bruce Albert, by virtue of Amazonian modes of existence, especially referring to the intensity of jungle spirits and experience Shamanic with spiritual worlds. In the context of a dispersed and outstanding plant extension, we affirm a daily sociability within the framework of a "respectful or loving ethic" among all life forms, aesthetically expressed in significant and transporting forms of emotions developed by Amazonian cosmology. For this we use the notions that Aby Warburg uses in his study of the culture of images, as a course by which they can be understood as living organisms susceptible to transformation, preserving their own biology in the coded transmission of memory.

Key words: Memory; survival (Nachleben); pathos formula (pathosformeln).

Davi Kopenawa nació en Toototobi, Brasil (1956), y quedó huérfano en la época en que las epidemias transmitidas por los primeros blancos visitantes diezmaron la selva (1950 a 1960). Siendo muy joven fue iniciado espiritualmente por su suegro, convirtiéndose en el dirigente de su comunidad Watoriki y en uno de los principales 
testigos de las oleadas de buscadores ilegales de oro, quienes esparcieron de nuevo en la zona enfermedades como la peste y la malaria. En este contexto, como representante político de las comunidades cazadoras y agricultoras de la selva tropical, distribuidas entre los ríos Orinoco (Venezuela) y Amazonas (Brasil), ha participado en organizaciones defensoras de los derechos del pueblo Yanomami y es actualmente activista por la libre autodeterminación de los pueblos de la selva y en particular de sus derechos de uso, conservación y sostenibilidad de esta.

El testimonio que aquí utilizamos se constituye de breves extractos (cap.4) del libro A queda do céu. Palavras de un xamã Yanomami (Companhia Das Letras, 2015) autoetnografía del chamán Yanomami Davi Kopenawa, en colaboración con el antropólogo francés Brus Albert ${ }^{2}$, quien a lo largo de décadas de amistad con el líder espiritual indígena, registra su historia de vida y traduce desde la lengua yanomami al francés, conservando la narración total en primera persona, afianzada por algunas palabras de la lengua original que otorgan contexto a la voz testimonial y que reafirman la supremacía de la voz nativa respecto del texto ilustrado moderno; al respecto J. Goddard afirma que la autoetnografía del chamán Kopenawa refleja la palabra "del hombre que vive, la contra-antropología sustituye la antropología oral, coerción y crítica, del hombre blanco por el indígena" (2016, p. 76). En el mismo sentido, nos parece que el testimonio amerindio "en su búsqueda de la pertinencia del leguaje con que se dice a sí mismo" (Cornejo Polar, 2003, p. 23), se desplaza desde el libro a la escucha del hombre blanco de pensamiento ahumado y absorto en el dibujo de su escritura autorreferencial. La voz, en consecuencia, prorrumpe con fuerza en el mundo otro, dialogando desde el trauma.

Añadimos a continuación un compendio de fragmentos del testimonio del chamán acerca de los animales ancestrales. Con la dificultad que impone la traducción de una cosmología amerindia a la racionalidad discursiva ilustrada, comprendemos que los espíritus descritos en la narración surgen al mismo tiempo como principios vitales o síntomas excepcionales y como imágenes de los seres de la selva actuales y de los antepasados de estos - una humanidad arcaica-, expresando a la vez la versatilidad con que los chamanes personifican diversas perspectivas.

OS ANCESTRAIS ANIMAIS

(...) Os xapiri são as imagens dos ancestrais animais yarori que se transformaram no primeiro tempo. É ese o seu verdadeiro nome. Vocês os chaman "espíritos" mas são outros.

\footnotetext{
${ }^{2}$ Su versión original, "La chute du ciel: Paroles d' un chaman yanomami” (Pocket Terre Humanine, 2010) fue traducida al portugués por Beatriz Perrone Moisés, existiendo además su adaptación al inglés por $\mathrm{N}$. Elliott y A. Dundy, bajo el título "Falling Sky. Words of a Yanomami Shaman" (2013). Hemos querido conservar el relato en su versión portuguesa, como una decisión que intenta detenerse en las particularidades de la narración y en las características del libro en general, en dicha versión y a diferencia de la edición en inglés, los testimonios se acompañan de correcciones, dibujos y mapas efectuados por Davi Kopenawa.
}

272 | AlPHA No 52 (JuLIO 2021) PÁGS. 271-289. ISSN 07 16-4254 
Vieram à existencia cuando a floresta ainda era joven. Os nossos antigos xamãs os faziam dançar desde sempre e, como eles, nos continuamos até hoje. Quando o sol se levanta ne peito do céu, os xapiri dormen. Quando volta a descer, à tarde, para eles o alvorecer se anuncia e eles acordam. Nossa noite é seu dia. De modo que, quando dormimos, os espíritos, despertos, brincam e dançam na floresta. Assim é. São muitos mesmo, pois não morrem nunca (...) en sus olhares, já somos fantasmas, porque, ao contrario deles, somos fracos e morremos com facilidade.

Os xapiri, no entanto, se parecem com os humanos. Mas seus pênis são muito pequenos e suas mos só têm alguns dedos. São minúsculos, como poeira de luz, e são invisíveis para a gente comuns, que só tem olhos de fantasma. Só os xamãs conseguem vê-los. Os espelhos sobre os quais dançam são inmensos. Sus cantos são magníficos e potentes. Seu pensamento é direito e trabalham com empmenho para nos proteger. Porém, se nos comportamos mal com eles, podem tambén ficar muito agressivos e nos matar (...) Os espíritos se deslocam por toda a floresta, como nós, quando caçamos. Mas eles não andam sobre as folhas podres e na lama, eles voam (...) Além disso, mesmo que fiquem muito velhos e cegos, os xapiri permanecen inmortais. Por eso eles aumentan sem parar na floresta. Os que dançam para os xamãs não passam de uma pequeña parte deles.

Para vê-los de verdade, é preciso beber o pó de yãkoana durante muito tempo e que os nossos xamãs mais velhos abram os caminos deles até nós. Isso leva muito tempo. Tanto quanto os filos de vocês levam para aprender os desenhos de suas palabras. É muito difícil. Contudo, quando faço dançar meus xapiri, às vezes os brancos me dizem: "Não se vê nada! Só se vê você cantando sozinho! Onde é que estão seus espíritos? (...) O pó da árvore yãkoana $h i$ não fez morrer seus olhos, como os dos xamãs. Então, por não poderem ver os xapiri, seu pensamento permanece fechado. Assim é. Os xapiri só dão a ouvir suas vozes se seu pai, o xamã, morrer com a yãkoana. Quando têm fome eles bebeb através dele. Só então podem descer sobre seus espelhos. Eles tembém morrem com a yãkoana, como seu pai, e assim começam a dançar e cantar para ele. Sem isso não porderiam ser vistos.

A imagen dos xapiri é muito reluzente. Estão sempre limpos, porque não vivem na fumaça das casas e não comem carne de caça como nós fazemos. Seus corpos nunca ficam cinzentos, sem pintura nem enfeites, como os nossos. Eles são cobertos de tinta fresca de urucum e enfeitados com pinturas de ondulações, linhas e manchas de um preto brilhante (...) Mas a pintura dos xapiri é um de seus bens preciosos. Provém dos odores misturados das coisas da floresta e não tem o cheiro acre e perigoso do álcool dos perfumes da cidade. Seus braços são enfeitados com muitos penachos de penas de papagaio e caudais de arara fincadas em braçadeiras de belas miçangas lisas e coloridas, com muitas e muitas caudas de tucano e despojos multicolores de pássaros wisawisama si pendurados. Têm um porte muito imponente! (...) Entretanto, existem tembém xapiri muito velhos, que já dançavam para nossos ancestrais (...) Até os seres maléficos os temem! São verdadeiros antepassados (...) os xapiri cintilam como estrelas que se deslocan pela floresta.

Em suas danças de apresentação, os xapiri agitam jovens folhas desfiadas de palmeiras hoko si, de um amarelho intenso e brilhante (...) Os cantos dos espíritos se sucedem um após o outro, sem tregua. Eles vão colhê-los nas árvores de antos que chamamos amoa hi. Omama criou esas árvores de línguas sábias no primeiro tempo, para que os xapiri possam 
ir lá buscar suas palavras (...) Cada xapiri possui seus própios cantos (...) Os cantos dos xapiri são tão numerosos quanto as folhas de palmeira paa hana que coletamos para cobrir o teto de nossas casas (...) Todos os cantos dos espíritos provêm dessas árvores muito antigas (...) Não se debe pensar que os xamãs cantam por conta propia, à toa (...) são imagens de melodías que vieram das árvores amoha hi (...) Preferimos guardar a voz dos espíritos no pensamento.

Os xapiri nunca se deslocan na floresta como nós. Descem até nós por caminos resplandecentes de luz, cobertos de penugem branca, tão fina quanto os fios das teias daaranha warea koxiki que flutuam no ar (...) Suas imagens são as de todos os habitantes da floresta que descem do peito do céu, um depois do outro, com seus filhotes.

Todos os seres da floresta possuem uma image, utupe. São esas imagens que os xamãs chaman e fazem descer. São elas que, ao se tornarem xapiri, executam suas danças de apresentação para eles. São elas o verdadeiro centro, o verdadeiro interior dos animais que caçamos. São essas imagens os animais de caça de verdade, não aqueles que comemos! (...) Mas só os xamãs podem vê-las (...) quando se diz o nome de un xapiri, não é apenas um espírito que se nomeia, é uma multidão de imagens semelhantes. Cada nome é único, mas os xapiri que designa são sem número. As imagens de animais que os xamãs fazem dançar não são dos animais que caçamos (...) Há muito e muito tempo, quando a floresta ainda era joven, nossos antepassados, que eran humanos com nomes animais, se metamorfosearam em caça (...) De modo que são esses ancestrais tornados outros que caçamos e comemos hoje em dia. As imagens que fazemos descer e dançar como xapiri (...) são seu verdadeiro coração, seu verdadeiro interior. Os ancestrais animais do primeiro tempo não desapareceram, portanto. Tornaram-se os animais de caça que moran na floresta hoje.

Os xamãs também fazem descer como xapiri as imagens de todos os seus habitantes: das árvores, das flohas e dos cipós, e ainda dos méis, da terra, das pedras, das águas, das corredeiras, do vento ou da chuva (...) No entanto, nem, todos os xapiri são habitantes da floresta (...) As imagens que os xamãs fazem dançar são sem número e suas palavras são mesmo infindáveis!

\section{MÍMESIS}

Tanto en la historia del arte y de la antropología del siglo XIX, la representación de seres animados, apariencias o acciones que los pueblos indígenas efectúan, tiende a ser concebida como literal. En este plano, una supuesta incapacidad para distinguir entre lo exterior y el Yo propio, propendería a hacerlos experimentar tanto las relaciones humanas como las cosas inanimadas, en el contexto de un mundo inmediato a la percepción humana. La conexión entre representación y cosa representada, sería por tanto real o no razonada (en ausencia del noema). En resumidas cuentas, imitativa.

Sin embargo, el testimonio que exponemos aquí, efectuado por Kopenawa, más que fundarse en la concesión generalizada de un alma a diferentes formas de existencia -como si hubiese una conciencia mimética primitiva confundida entre lo real e imaginario-, deja ver más bien, un especial modo de crítica en el contexto de una "modernidad heterogénea" 
(Cornejo Polar, 1978) donde la memoria indígena advierte de su propio modo de subjetivación y producción realizativa del habla (Austin, 2018) en contraste ontológico con la civilización industrial. Acerca de este mismo asunto, Carlo Severi (2010) siguiendo el modelo de asociaciones de R. Vischer, afirmará que en ciertas circunstancias podemos quedarnos prendidos anímicamente frente a un signo o una imagen, sin constituir una relación de semejanza total o de causalidad con algo, y sin establecer ideas o conceptos para formarnos un juicio. En estas circunstancias, más bien caemos en el espacio donde el sentido se consume a sí mismo figurado en pensamiento mágico; desde este lugar, el testimonio de Kopenawa presenta algo más que información relativa al mundo, no expresa solo la necesidad de dar cuenta al hombre ilustrado acerca de la vida en la selva; como discurso cumple una función bastante más amplia que afirmar que algo es o no es, en la medida que al pronunciarlo, "en ciertas circunstancias, se lleva a cabo una función que no debe confundirse con la acción de pronunciarlo" (Austin 2018, p. 31), en definitiva, lo que se expresa aquí posee una fuerza comunicativa y conceptual performativa, decir algo implica la realización de al menos una parte de lo que se dice en la realidad, lo que se lleva a cabo al decir porta la fuerza significante del discurso, alterando la condición de lo que se dice. Se revelan así, los principios hacedores de mundo, conforme al análisis de J. Goddard, acerca del mismo testimonio, A queda do céu expone la "episteme del sueño" chamánicobajo la influencia del yãkoana- (p. 81). Si podemos advertir que en Amazonía, cada especie posee disposiciones corporales distintivas que le dan acceso a mundos particulares, de modo tal que cada existente se caracterizaría no precisamente por una cultura específica sino que por las facultades alojadas en su cuerpo ${ }^{3}$, los espíritus tan numerosos no solo estarían reflejando a los seres del pasado, sino revelarían una multiplicidad de imágenes selváticas táctiles y sonoras, presentes y futuras, incluyendo las relaciones en el tenor de "los órdenes estériles de la técnica y de la producción capitalista" (p. 80).

Esta forma de existencia conformada en el imaginario amazónico, traspasa a nuestro juicio la relación directa entre lo sensible y lo inteligible, como tradicionalmente tienden a sancionar desde el espacio ilustrado, nuestros significados. Desde esta postura, distinguimos una constante mudanza, un modo de ser o una actitud sobre las materias cambiantes y que en la sociedad indígena descrita por Kopenawa, se impone como reflexividad no proposicional, pero no indeterminada, quizás una manifestación de lo inseparable del conocer/actuar, pensar/sentir (Viveiros de Castro, 2009; Berque, 2009). La movilidad de seres y materias selváticos, de acuerdo con la experiencia del

\footnotetext{
${ }^{3}$ Autores como Phillipe Descola (2005, 2016), Tania Stolze Lima (2005) o Viveiros de Castro (2009), coinciden en afirmar que las determinaciones corporales de especies humanas y animales en Amazonía, propician un punto de vista que varía según el medio vital, los modos de percepción, defensa y locomoción, entre otros. Y son estas facultades y estas perspectivas, los que propician modos de existencia diferenciados de las formas de vida y razón occidental. Filosóficamente, la obra de F. Nietzsche profundiza este asunto acerca del perspectivimso, ver por ejemplo, La Gaya Ciencia (1882).
} 
antropólogo Roy Wagner ${ }^{4}$ no puede ser comprendida como un engranaje aleatorio de ideas, instituciones y comportamientos internalizados de forma mecánica, sino como un flujo evocado, suscitado, representado y que se mueve dialécticamente entre lo convencional/colectivo y lo personal/subjetivo; la reminiscencia de Kopenawa impulsa una sabiduría que va más allá de la imitación a partir de ciertas correspondencias sintetizadas a lo largo del tiempo:

Para vê-los de verdade, é preciso beber o pó de yãkoana durante muito tempo e que os nossos xamãs mais velhos abram os caminos deles até nós. Isso leva muito tempo. Tanto quanto os filos de vocês levam para aprender os desenhos de suas palabras. É muito difícil 5 .

En la percepción del hombre común, la narración del pensador indígena Kopenawa, opera como un documento memorioso y relato ejemplar, aun cuando este no experimente la vivencia sensorial primaria de origen, es decir, el momento en que todas las existencias se encontraban reunidas en tiempos originales o también, la visión de los espíritus xapiripë provocada por la exhalación mágica del humo del árbol yãkõanahi'

Contudo, quando faço dançar meus xapiri, às vezes os brancos me dizem: "Não se vê nada! Só se vê você cantando sozinho! Onde é que estão seus espíritos? (...) O pó da árvore yãkoana hi não fez morrer seus olhos, como os dos xamãs. Então, por não poderem ver os xapiri, seu pensamento permanece fechado. Assimé. Os xapiri só dão a ouvir suas vozes se seu pai, o xamã, morrer com a yãkoana. Quando têm fome eles bebeb através dele. Só então podem descer sobre seus espelhos. Eles

\footnotetext{
${ }^{4}$ Wagner efectúa sus principales investigaciones entre los Daribi, en Mount Karimui, Nueva Guinea, a fines de los 60 . Su preocupación por la “invención cultural”, es decir, respecto de la producción de sentido, la comprende en tanto proceso móvil y reversible de ideas y comportamientos escenificados, representados, los que definitivamente emplazarían los órdenes convencionales de mundo, provocando ciertas transformaciones en espacios enigmáticos, performativos, intersticiales. A esta perspectiva de análisis dentro de los estudios de los símbolos, la religión y mitología, se le ha denominado "antropología inversa".

5 (...) Para verlos de verdad es necesario beber el polvo del yãkoana durante mucho tiempo y que nuestros chamanes más viejos abran los caminos de ellos ante nosotros. Eso lleva mucho tiempo. Tanto como los hijos de ustedes tardan en aprender a dibujar sus palabras. Es muy difícil (traducción del autor).

${ }^{6}$ Los espíritus descritos emergen como manifestación simultánea de las imágenes de los seres de la selva actuales y de los antepasados de estos, expresando a la vez, la cualidad de transformación de ciertos humanos, los chamanes, pues el término xapiripë, "se refere também aos xamãs humanos, e a expressão 'tornar-se xamã' é sinônima de "tornar-se espírito", xapiri-pru. Os xamãs se concebem como de mesma natureza que os espíritos auxiliares que eles trazem à terra em seu transe alucinógeno" (Viveiros de Castro, 2006, p. 321) Esta región ambigua entre las identidades de lo humano y las otras formas de existencia, en la experiencia sagrada, narrada por Davi K., comunica el sustrato humano originario, oculto por las formas animales, y suma las variadas afecciones que deben ser captadas/sentidas por quienes escuhan, por medio de la voz del chamán en su rol de portador de sentido. Todo ello una vez que él, ha oído las palabras de los xapiripë.
}

276 | ALPHA No 52 (JULIO 2021) PÁGS. 271-289. ISSN 07 16-4254 
tembém morrem com a yãkoana, como seu pai, e assim começam a dançar e cantar para ele. Sem isso não porderiam ser vistos ${ }^{7}$.

A pesar de la privación de vivenciar de manera directa el encuentro mágico por los jóvenes, aquellos que no detentan el rol de chamán o por el hombre blanco, la síntesis mnémica, el archivo ejemplar, establece una relación con lo real de todas maneras; reafirmando esta perspectiva, R. Wagner insistirá en que la producción de sentidos subsume, o soterra las relaciones convencionales entre fenómenos, por obviación. Si seguimos entonces este punto de vista, la creciente de metáforas consecutivas en la narración del chamán verticalizan el esquema de realidades diversas, actualizándolas gracias a la participación de todas las generaciones, en la sincronía y diacronía sagradas:

os xapiri agitam jovens folhas desfiadas de palmeiras hoko si (...) Omama criou esas árvores de línguas sábias no primeiro tempo, para que os xapiri possam ir lá buscar suas palavras (...) Todos os cantos dos espíritos provêm dessas árvores muito antigas (...) Não se debe pensar que os xamãs cantam por conta propia, à toa (...) são imagens de melodías que vieram das árvores amoha hi (...) Preferimos guardar a voz dos espíritos no pensamento . $^{8}$

La forma sui generis en que el imaginario sagrado testimonia, denota la realidad indirectamente aludida por las representaciones sociales y muestra su estética ligada a la temporalidad y movimiento de las materias en cuanto ritmos de existencia móvil y heterogénea. Este régimen cultural amazónico, volcado en el relato del chamán, expone las condiciones generales de existencia de las relaciones humanas como de todo lo vivo"; e independientemente a una veracidad o falsedad empírica, la comparación ontológica que el discurso original de producción de conocimiento indígena y su transmisión en sueños, visiones, relatos o cantos, hace con el "pensamiento cerrado blanco", conduce a

\footnotetext{
7 “ (...) Sin embargo, cuando hago bailar a mis xapiri, a veces los blancos me dicen: No se ve nada! Solo se te ve cantando solo. Dónde están tus espíritus? (...) El polvo del árbol yãkoana hi no hace morir sus ojos como los de los chamanes. Entonces por no poder ver a los xapiri, su pensamiento permanece cerrado. Así es. Los xapiri solo permiten escuchar sus voces si su padre, el chamán, muere con el yãkoana. Cuando tienen hambre ellos beben a través de él. Solo entonces pueden descender sobre sus espejos. Ellos también mueren con el yãkoana, como su padre y así comienzan a bailar y cantar para él. Sin eso no podrían ser vistos" (traducción propia).

8 “ “...) los xapiri agitan jóvenes hojas deshilachadas de palmeras hoko si (...) Omama creó esos árboles de lenguas sabias en el primer tiempo, para que los xapiri puedan ir allá a obtener sus palabras (...) todos los cantos de los espíritus provienen de esos árboles muy antiguos. No se debe pensar que los chamanes cantan por cuenta propia, para nada (...) son imágenes que vinieron de los árboles amoha hi (...) Preferimos guardar la voz de los espíritus en el pensamiento" (traducción propia).

${ }^{9}$ Nos importa en este asunto, recalcar que usamos las nociones de "lo vivo" o "lo existente" en la óptica de una etología filosófica, incluyendo a aquellas formas de subjetivación espirituales; no utilizamos la noción de lo "no humano", porque ello implicaría en nuestra reflexión considerar incluso, las relaciones simbólicas y materiales que los humanos mantienen con las máquinas.
} 
la pregunta política por los criterios de juicio acerca de la diferencia entre los pueblos, respecto de la noción progresiva de la historia y su consecuente degradación -si se quiere reificación también- como experiencia de alienación de la naturaleza -versus la aprehensión del fenómeno de lo vivo en una ecología de las existencias compartidas ${ }^{10}{ }^{-}$. En este sentido, la razón soberana propiciada por cierto pensamiento filosófico, biológico y teórico de corte separatista entre animales, plantas y humanos, reafirma el deseo ávido del pensamiento blanco que, según Kopenawa, se expresa en las distintas oleadas extractivistas de saqueadores de oro, comunidades religiosas o agrupaciones estatales de control indígena que han socavado a la Amazonía en lo material y valórico ${ }^{11}$.

El testimonio de Kopenawa se afinca en los muchos tiempos incontables, insertos en un tiempo cuya movilidad desplaza la fijeza unánime de la representación imitativa, esto último afianza entonces el cariz realizativo que seres y cosas pueden poseer en la cognición amazónica, donde cada detalle expresa la multiplicidad intensiva ${ }^{12}$ de los cuerpos, pero a su vez, permite el desenvolvimiento táctil de estos: en el caso Yanomami expuesto, las imágenes utupë son algo más que una proyección hacia el exterior, son el aspecto interno pero no mental de la flora y fauna de la selva (Viveiros de Castro 2006) -los antepasados-no son una materialidad del todo opuesta a lo inmaterial ya que poseen una fisicalidad en el cuerpo del chamán -al ser él mismo, el soporte de un utupë- como también en el xapiripë centelleante, colmado de reflejos:

A imagen dos xapiri é muito reluzente. Estão sempre limpos (...) Seus corpos nunca ficam cinzentos, sem pintura nem enfeites, como os nossos (...) Descem até nós por caminos resplandecentes de luz, cobertos de penugem branca, tão fina quanto os fios das teias daaranha warea koxiki que flutuam no ar (...) Suas imagens

\footnotetext{
${ }^{10}$ Ha sido un asunto común del pensamiento occidental, la diferenciación universal del hombre entre los seres vivos como la subordinación de ellos a este, incluso estableciendo como punto cúlmine de lo vivo, al hombre. Dominique Lestel, filósofo y etólogo francés, propone pensar "el animal" - denominación que incluye simétricamente al humano - en el sentido de una superposición de virtualidades y transformaciones de lo vivo, como una "agencia" de estatutos múltiples y hasta contradictorios entre si: "pensar lo vivo como tal y no solo al viviente biológico, o lo que una época dada en un lugar particular quisiera considerar como vivo. Añadiría incluso: y en todos los planetas y en todos los universos posibles" (2018).

11 "Y más tarde dirás a tus hijos: Estas palabras escritas son las de un Yanomami, que hace mucho tiempo me contó cómo él se convirtió en espíritu y de qué modo aprendió a hablar para defender a su selva". Kopenawa solicita a Bruce Albert registrar por escrito sus reflexiones en conjunto para la difusión de su pensamiento y defensa medioambiental ante diversas autoridades mundiales, traducción nuestra (2010).

12 Contrario a un proceso de reducción de la cosa, idea o palabra, para unificar en un conjunto, lo "intensivo" en el sentido de Deleuze y Guattari, aparece como múltiple contagio/cambio de elementos o de atributos y que deviene: "Nosotros sabemos que entre un hombre y una mujer pasan muchos seres, que vienen de otros mundos, traídos por el viento, que hacen rizoma alrededor de las raíces, y que no se pueden entender en términos de producción, sino únicamente de devenir (...) La manada es a la vez realidad animal y realidad del deveniranimal del hombre" (2015).
}

278 | ALPHA № 52 (Julio 2021) PÁGS. 271-289. ISSN 07 16-4254 
são as de todos os habitantes da floresta que descem do peito do céu, um depois do outro, com seus filhotes ${ }^{13}$.

La tactilidad es parte de un proceso sinestésico de recuerdo, inserto en la praxis de colección y expediente de la memoria amazónica, donde las personas -objetos y seres pasibles de un punto de vista- encorporan: los utupë, imágenes de un algo que no puede ser advertido por la visión, son en rigor, índices ${ }^{14}$ que nos interpretan y nos transforman, antes que los originemos:

São minúsculos, como poeira de luz, e são invisíveis para a gente comuns, que só tem olhos de fantasma. Só os xamãs conseguem vê-los ${ }^{15}$.

Se trataría más bien de una intencionalidad de los espíritus de la naturaleza, en tanto agencia y devenir animal del hombre, efectuación de una potencia de manada o de multiplicidad si se quiere ${ }^{16}$ :

quando se diz o nome de un xapiri, não é apenas um espírito que se nomeia, é uma multidão de imagens semelhantes ${ }^{17}$.

Los ütupe por tanto, actualizarían el imaginario colectivo en términos de un campo anímico, como también mediante un carácter inmediato y sobre todo performativo pues, en su imperativo de continuar existiendo, los utupë instan tanto al chamán y a aquellos a quienes el chamán trasmite la tradición, la responsabilidad de otorgarles pervivencia en la propia identificación de un "nosotros", entidad que ellos ayudan a crear.

Esta estética de los reflejos, desde donde los humanos convergen en la perspectiva animal y vegetal, devela las relaciones diversificadas entre personas, cuerpos y esencias, para así conformar una impresión particular de las sinestesias posibles en los planos de la narración chamánica, sumadas al componente psíquico de imaginación en el que la vida

\footnotetext{
${ }^{13}$ (...) La imagen de los xapiri es muy reluciente. Están siempre limpios (...) Sus cuerpos nunca quedan opacos, sin pintar ni embellecer, como los nuestros (...) Bajan ante nosotros por caminos resplandecientes de luz, cubiertos de un plumaje blanco tan fino como los hilos de telas de araña warea koxiki flotando en el aire (...) Sus imágenes son las de todos los habitantes de la selva que descienden desde el pecho del cielo, unos después de otros, con sus cachorros (traducción propia).

${ }^{14}$ De acuerdo a Charles Peirce, el signo está ligado al objeto en virtud de una asociación mental, y depende por tanto de un hábito. Estos signos son siempre generales y, con frecuencia, convencionales y arbitrarios. Si el signo, en cambio, significa su objeto solo sobre la base de una conexión real con él, como ocurre con los signos naturales y con los síntomas físicos, este signo es llamado índice. "El índice no afirma nada; solamente dice ¡Allí!’ (Fumagalli, 1996).

${ }^{15}$ (...) Son minúsculos como polvo de luz y son invisibles para la gente común que solo posee ojos de fantasma. Solo los chamanes consiguen verlos (traducción propia).

${ }^{16}$ De acuerdo a los mismos filósofos (D. y G), el "afecto", no corresponde a un sentimiento personal o a un carácter particular, es "la efectuación de una potencia de manada que hace vacilar al Yo".

${ }^{17}$ (...) Cuando se pronuncia el nombre de un xapiri, no es apenas un espíritu el que se nombra, es una multitud de imágenes semejantes (traducción propia).
} 
de la selva reverbera poéticamente, constituyendo una experiencia estética provista por la suspensión provisoria del imperativo de los significados, desorientando la atención y confrontando con lo desconocido como ilusión perceptiva sonora: allí pareciera ser posible oír las palabras de los xapiripë ante el fatuo destello de sus reflejos.

\section{NARRACIÓN Y MEMORIA}

$\mathrm{Al}$ respecto, y continuando con el citado modelo de asociaciones de $\mathrm{R}$. Vischer, el historiador del arte Aby Warburg, afirmará que la fuente desde donde nace la empatía, la emoción de una energía peculiar encarnada en modelos temporales, corporales o semióticos, proviene de la proyección de una imagen latente de nosotros (Warburg, 2005), siendo esta una fuerza emotiva suficiente para comprometer nuestra imaginación con lo representado en la percepción y consecutivamente, el encadenamiento con nuevas asociaciones, enriquece así la experiencia. Aspectos antes señalados y este último, la proyección posterior hacia el acontecimiento narrativo, enfatiza el impulso empático hacia el flujo del relato chamánico, siempre dinámico, generando el grado cero de la experiencia estética amazónica, si se considera que el grado cero de la poesía y de la ficción puede ser comprendida como una reverberación o la resonancia de un movimiento (Librandi Rocha, 2012). En esta estética de los reflejos, la reverberación, el eco de las palabras de Kopenawa, tiende aquí a proporcionar un tránsito posible hacia lo real y en su ajetreo de luces y sombras, no apaga del todo la subjetividad del narrador, y concede -gracias a la diferenciación e identificación simultáneas- la producción de una experiencia de enculturación y socialización de la memoria, como a la vez, de un placer que no solo surge del reconocimiento sino del conocimiento acerca de la propia producción de una realidad indígena.

La narración de Davi Kopenawa visualiza lo invisible, refleja los preceptos de los diversos personajes y sus acciones posibles de manera caleidoscópica:

Entretanto, existem tembém xapiri muito velhos, que já dançavam para nossos ancestrais (...) Até os seres maléficos os temem! São verdadeiros antepassados (...) os xapiri cintilam como estrelas que se deslocan pela floresta ${ }^{18}$.

En tiempo presente, las fuerzas destructivas de siglos anteriores en Amazonía, se exteriorizarían de manera inconsciente en la narratividad trascendente contemporánea, mediante la intensa expresión motriz y psíquica de los cuerpos humanos, de otras especies y su comunicación como imágenes dialécticas en el presagio del desastre ambiental

\footnotetext{
${ }^{18}$ (...) Sin embargo, existen xapiris muy viejos, que ya bailaron para nuestros ancestros (...) Hasta los seres maléficos les temen! Son verdaderos antepasados (...) los xapiri brillan como estrellas moviéndose por la selva (traducción propia).

280 | AlPHA № 52 (JuLIO 2021) PÁGS. 271-289. ISSN 07 16-4254
} 
contemporáneo ${ }^{19}$. En la perspectiva de Warburg, la proyección que Kopenawa plasma en su imagen psíquica sobre los xapiripë, resulta absorber el traumatismo latente y así mismo la voluntad de aniquilamiento respecto de esa latencia, acarreando a nuestro juicio, un hiato de significación por el que la apertura del enigma angustioso, es decir; la desavenencia entre conciencia y mundo, afianza desde la experiencia proyectiva, una exploración imaginativa de las épocas actuales, en las que el chamán participa.

Desde esta posición, entre el lapsus de lo que se "acerca" y "se rechaza a la vez", nos parece que los estilos figurativos, creencias y símbolos yanomami descritos por el chamán por medio de la imagen de los xapiri, contendrían ciertas "concentraciones" inmanentes de un flujo transindividual entre lugares y tiempos heterogéneos $\left(\right.$ Pathosformeln $\left.{ }^{20}\right)$. Nos referimos aquí otra vez, no a un carácter ni a una identidad particular, sino a una psique transversal y común a lo que se ha denominado cuerpo y alma; en palabras de Didi Huberman (2018), antropológicamente central a aquello que la estética clásica empobrece un tanto bajo el concepto de imitación, dejando de lado un aspecto de la animación, como señalábamos, que no es solo un intento por adjudicar a un cuerpo yacente o invisible cierta energía animal, sino que fenomenológicamente hablando, ahonda en el "movimiento de la supervivencia" como un contrarritmo al "movimiento de la vida" (p. 172). ¿Cuáles son las formas del tiempo superviviente en la imagen del xapiripë? De acuerdo con Warburg, la fórmula de pathos se reconoce en la personificación en los cuerpos, formas y esencias de una causa exterior y deseosa de expresar la gestualidad afectiva de la presencia -de un estado original Yanomami- revivida de manera apasionada por los sujetos y en relación con la volencia transcultural originada por los madereros, buscadores de oro ilegales, como por el mismo Estado. En la narración, los ornamentos de los espíritus y sus bailes de movimientos agitados denotan el ritmo libre y el frenesí patético de la reluciente belleza ancestral expresados en forma paralela al temor que suscitan, en este sentido, la pathosformeln reafirma a la imagen de los xapiripë en un régimen doble de "la fuerza con la forma, la temporalidad de un sujeto con la espacialidad de un objeto (...) un trazado en acto de las imágenes antropomórficas" (p. 179):

Têm um porte muito imponente! (...) Em suas danças de apresentação, os xapiri agitam jovens folhas desfiadas de palmeiras hoko si, de um amarelho intenso e brilhante (...) Os cantos dos espíritos se sucedem um após o outro, sem tregua ${ }^{21}$.

\footnotetext{
${ }^{19}$ En el primer tiempo Yanomami, el cielo hubo de incendiarse y caer sus cenizas a la tierra, sobre las que, nuevas familias de todas las especies comenzaron la vida. En “A Queda de Céu”, Kopenawa recupera la imagen de la caída de origen, para presagiar el apocalipsis de la selva como del hombre blanco.

${ }^{20}$ Concepto elaborado por A. Warburg y traducido como fórmula de pathos ofórmula patética.

21 “(...) Tienen un porte muy imponente! (...) En sus bailes de presentación los xapiri agitan hojas deshilachadas de palmeras hoko si, de un amarillo intenso y brillante (...) los cantos de los espíritus se suceden uno después de otro sin descanso" (traducción propia).
} 
Los utupë, por su parte, en la lógica de análisis de Warburg, vienen a manifestarse no solo como propias de un tiempo cronológico sino ante todo, como supervivencias (Nachleben ${ }^{22}$ ) de un tiempo psíquico donde se manifiesta la actualidad de lo primitivo ${ }^{23}$ (En D. Huberman, 2018). En orden a la narración de Davi Kopenawa, las figuras de los utupë, como intencionalidades no materiales, resultan en dispositivos de imaginación, cumpliendo una función imperativa y debatida en la polaridad de las cosas del mundo. Son la pervivencia de una fuerza, de una intensidad por la que el pasado podría redimirse gracias a una convergencia -y no solo una relación- del hombre con la naturaleza, la cosmología Yanomami que Kopenawa rescata, respondería contemporáneamente a una órbita de analogías anímicas donde los muertos, vivos, blancos, animales, antepasados y espíritus xapiripë, devienen más bien, en acontecimiento de fractura, haciendo visible el estado afectivo de la comunidad, en otras palabras participando de un gesto psíquico, de una fórmula patética que es testimonio de "un estadio desaparecido de la sociedad cuya persistencia ha modificado su significación y estatus" (Huberman 2018, p. 52).

\section{ORALIDAD Y SÍNTOMA DE PERVIVENCIA}

Hemos intentado establecer antes una articulación entre las palabras del chamán y las imágenes que ellas refieren, fundadas en el ejercicio de la memoria ancestral y extensiva a la remembranza colectiva desde la empatía mimética. En su vínculo mental con el mundo, la tradición oral Yanomami modela su praxis en el retorno de los detalles o "rasgos salientes" 24 que la enunciación narrada reitera en secuencias ordenadas o con imágenes tipo en presente y pasado, ya sea en el flujo del mensaje o en su transmisión a lo largo del tiempo. Asímismo, las imágenes aludidas por Davi Kopenawa son controladas en el uso del lenguaje y en el contexto de lo sagrado, permitiendo que la imaginación poética expanda un campo psíquico interno -cuya necesidad no es solo la de 'contar' sino la de celebrar- de ritualización con otros ${ }^{25}$ más allá del contenido,

\footnotetext{
${ }^{22}$ Noción originalde la antropología anglosajona bajo el término survival, desarrollado por Edward B. Taylor y que en términos muy sencillos se pregunta por las maneras en que el presente se constituye gracias a una multiplicidad de pasados, complejizando los sentidos culturales. En el estudio Warburgiano, el nachleben será desarrollado como una supervivencia, una pervivencia, cierta tenacidad de la antigüedad por dejar su huella no solo en restos materiales, sino ante todo en comportamientos, formas, estilos de un grupo cultural, en definitiva, en el psiquismo de este: "el análisis de las supervivencias se nos presenta como el análisis de manifestaciones sintomáticas tanto como fantasmales" (Huberman, 2018, p. 52).

${ }^{23}$ Entiéndase aquí por primitivo, a aquellos rasgos pulsionales, fantasmáticos, latentes o críticos de la fórmula de pathos.

${ }^{24}$ Metodológicamente, en sus investigaciones acerca del ritual y la imagen, Carlo Severi, antropólogo italiano, utiliza esta denominación para referirse, a la figura de supervivencia Warburgiana.

${ }^{25}$ Los otros, quienes le escuchen en su propia cultura y le lean fuera de su cultura, a través del registro de sus testimonios y su labor como representante político en organizaciones internacionales de corte medioambiental. 282 | AlPHA № 52 (Julio 2021) PÁGS. 271-289. ISSN 07 16-4254
} 
proyectando en la palabra, la imagen-recuerdo ${ }^{26}$, de una sinestesia que conecta diferentes registros de la percepción colectiva y que asocia en la voz de Kopenawa, la presencia de aquellos que provienen de los "árvores, das flohas e dos cipós, e ainda dos méis, da terra, das pedras, das águas, das corredeiras, do vento ou da chuva"; la voz aquí, lleva a término la imagen de los antepasados de la selva, los xapiripë, en cuerpo múltiple, constituido por lo humano, lo animal/vegetal y extrahumano: chamán, animales de caza, espíritus tradicionales.

Los ancestros, espíritus de la naturaleza, afloran en la narración del chamán en su configuración 'quimérica' (Severi, 2010) es decir, aunando cuerpos en un solo cuerpo o variados rasgos contradictorios en una sola imagen, tal como Warburg caracterizará a esta fórmula con el nombre de "dialéctica del monstruo". En nuestro caso, la imagen del xapiripë es el 'nudo de anacronismos' Warburgiano: los espíritus son descritos como danzantes desde el primer tiempo hasta el actual, parecidos a los hombres, coloreados con el tinte de semillas y ornamentados con plumas, perlas y espejos; son imágenes descendientes del cielo de la selva, auxiliares del chamán en su metamorfosis como espíritu, imágenes de los padres de los animales, los antepasados y sumado a todo ello, evocación de los múltiples desastres que el hombre blanco efectuó y advertencia crítica de un presente y futuro en ofensiva con la sociedad industrial. La fórmula de phato ${ }^{27} \mathrm{del}$ xapiripë prorrumpe el relato memorioso y ejemplar del chamán, para filtrar el pasado psíquico, que "tiene como característica, el no ser (...) aniquilado por sus retoños; se mantiene al lado de lo que ha llegado a ser, ya sea de manera solo virtual, ya sea en una real contemporaneidad" (Huberman 2018, p. 223). Desde este ángulo, la imagen y figura de los espíritus es biológicamente necesaria como método retrospectivo respecto de la producción de las formas expresivas materiales y virtuales; su registro anímico, la imagen teriomórfica de 'los espíritus de la selva' con sus detalles y adornos, carga consigo la huella mnémica originaria, a saber, el utupë, o si se quiere, la fuerza que habita la selva, una pulsión primitiva diseminada en el ecúmene amazónico: la humanidad arcaica; representación ética de las reacciones de los pueblos Yanomami frente al apremio industrial brasileño actual: "Los blancos exterminan humanos y no humanos y cuelgan cosas muertas en las paredes. Cosas que denominan símbolos" (Kopenawa, 2019)28 y a su vez entidad horizontal frente a la figura de Cristo, símbolo reverso de los primeros contactos traumáticos con el hombre blanco y su corrupción.

Esta idea de una sobrevivencia de la Antigüedad, desarrollada aquí en relación con A. Warburg en el campo del análisis de la imagen, ha sido estudiada también en el ámbito

\footnotetext{
${ }^{26}$ Warburg llama a la imagen-recuerdo, engrama, caracterizándola como una formación portadora de memoria, en definitiva una impronta del tiempo, la vida y sus movimientos, una corporeización en la imagen, de lo psíquico y plástico: Cuerpo del que surge de modo repentino una imagen rechazada (Huberman, 2018).

${ }^{27}$ Una pasión que oscila entre lo apolíneo y lo dionisíaco, de acuerdo al autor.

${ }^{28}$ Conferencia Amazonia and our planetary futures. Universidad de Harvard (EE UU),7 de Mayo del 2019.
} 
de las literaturas andinas, por A. Cornejo Polar en su exposición sobre "El diálogo de Cajamarca" de 1532. Dicho evento narrado, comprendido como un temprano ejemplo ${ }^{29}$ de las contradicciones temporales que conforman la literatura latinoamericana, deja ver las contratransferencias entre las descripciones de los cronistas (escritura) y el hecho concreto de la recepción de un breviario eclesiástico, por Atahualpa (oralidad). De acuerdo con Cornejo Polar (2003) en las múltiples versiones de los cronistas, en las que se describe e interpreta el encuentro entre el fraile Valverde y Atahualpa, subyace una violencia colonial que les convierte en cómplices indirectos de la dominación ilustrada respecto de las epistemologías indígenas; es decir, se soslaya el problema de traducción cultural, justificando la preeminencia oral del Inca como argumento de ignorancia y beligerancia ante el código escritural de la palabra religiosa europea. A este respecto, la extensión del evento del siglo XVI a la estructura de la literatura latinoamericana actual, según el autor, traspasa dichas contrariedades a los contenidos de representación de otros géneros incluso, como la danza , canciones rituales y el teatro; a nivel local señala, tanto en los gestos y movimientos performativos de estas puestas en escena, en cada pueblo sobreviven y se rechazan, actualizan o modifican, los argumentos de condena sin razón ni justicia de Atahualpa y de forma consecutiva de las oleadas de violencia material y extractiva de la conquista europea en el continente americano.

En consecuencia, el análisis anterior nos ayuda a fortalecer la idea de varias conciencias temporales y afectivas presentes en la narración de Kopenawa, las que le desbloquean permitiendo extenderse más allá de sí misma, gracias a las potencialidades psíquicas, plásticas y sinestésicas de las reminiscencias chamánicas. Estas, incrustadas en la expresión de una escatología de la multiplicidad, afectan la memoria social depositando residuos vitales de un momento original, un espacio, tiempo o movimiento previo a un ordenamiento lógico o causal y proclive a la catástrofe. Gracias a su metamorfosis chamánica, Davi Kopenawa, celebrante y espíritu invocado, coincide ontológicamente con los ancestros de la naturaleza utupë, los primeros humanos. Para encarar las habilidades físicas y motrices de los antiguos padres de la selva ${ }^{30}$, el chamán ha de realizar una transformación análoga y es por ello que el testimonio de Kopenawa evoca y conmemora la palabra caleidoscópica de los seres de la selva, corporizándolos en su voz y encarnando él mismo en espíritu xapiripë. En consecuencia, la identificación del chamán con los espíritus videntes de la selva, cristaliza un proceso acumulativo de opuestos (humano/animal/vegetal, material/extrahumano, diacronía/sincronía, agonía de la selva/frenesí de esta) que expresados en la narración, configuran un campo anímico particular -la expresión del ser del hombre y su destino-, elaborando también, un flujo

\footnotetext{
${ }^{29}$ El autor utiliza la noción de "escena primordial" para definir este acontecimiento, noción acuñada por Max, Hernández en su análisis sobre las consecuencias de la conquista española. En C. Polar (2003).

${ }^{30}$ Recordemos la mutación: de primeros humanos sagrados, a espíritus tutelares de la selva; en algunos casos degradados a animales de caza.

284 | AlPHA № 52 (Julio 2021) PÁGS. 271-289. ISSN 07 16-4254
} 
pulsional profundo; aquí las fuerzas en movimiento de la imaginación -si quiere llamársele así a la apertura de mundos posibles- no aporta una identidad alternada, sino paradojal por acumulación de sentidos. En los mismos términos, la posición de Cornejo Polar ha sostenido que el sujeto amerindio fue construido de modo inestable, debido a una abigarrada relacionalidad con la alteridad: "la englobante condición colonial de las Indias, condición que destrozaba al sujeto y pervertía todas las relaciones (consigo mismo, con sus semejantes, con los nuevos señores, con el mundo, con los dioses, con el destino y sus deseos) que lo configuran como tal" (2003, p. 13) y es esa heterogeneidad dispar, reversible, la que también devela cierta condición archipelágica o vertical en el discurso de Kopenawa.

Asimismo, los rasgos salientes de la caracterización de los espíritus, de una intensidad particular -cuerpos en movimiento afectados por las pasiones-, enseñan la actividad mental de la imaginación Yanomami, en tanto desciframiento, proyección y sedimentación paralela de formas orales y visuales en movimiento reversible (Wagner, 1986); los detalles táctiles de la narración son las primeras vías de referencia y sentido donde se asienta la tradición -siempre fisurada, según C. Polar-, ellos son el pivote de la incorporación simultánea de la lengua, de los principios culturales y psicológicos, como de las relaciones entre las existencias compartidas. Las imágenes descritas por Kopenawa son síntomas de forma compleja, de rasgos que se cristalizan en el recuerdo, "fósiles en movimiento. Supervivencias encarnadas (...) capaces de conmover el presente mismo de nuestros propios gestos" (Warburg en Huberman 2018, p. 182) Estos, en primer término suscitan un flujo memorioso hacia el futuro, porque imponen la responsabilidad de guardar la sabiduría de los espíritus en el pensamiento:

Seu pensamento é direito e trabalham com empmenho para nos proteger. Porém, se nos comportamos mal com eles, podem tambén ficar muito agressivos e nos matar (...) Além disso, mesmo que fiquem muito velhos e cegos, os xapiri permanecen inmortais ${ }^{31}$.

Asimismo, evocan:

Os xapiri são as imagens dos ancestrais animais yarori que se transformaram no primeiro tempo. É ese o seu verdadeiro nome. Vocês os chaman "espíritos" mas são outros. Vieram à existencia cuando a floresta ainda era joven. Os nossos antigos xamãs os faziam dançar desde sempre e, como eles, nos continuamos até hoje ${ }^{32}$.

\footnotetext{
31 “(...) Su pensamiento es directo y trabajan con empeño para protegernos. Po eso, si nos comportamos mal con ellos, pueden volverse agresivos y matarnos. Además, incluso si se vuelven muy viejos y ciegos, los xapiri permanecen inmortales" (traducción propia).

32 “(...) Los xapiri son las imágenes de los animales ancestrales yayori que se transformaron en el primer tiempo. Es ese su nombre verdadero. Ustedes los llaman “espíritus" pero son otros. Vieran su existencia cuando la selva todavía era joven. Nuestros antiguos chamanes los hacían bailar desde siempre y como ellos, nosotros continuamos hasta hoy" (traducción nuestra).
} 
Y en último término, legitimando ciertos conocimientos enigmáticos asociados a la trasformación de los cuerpos y afianzando la exuberancia e intensidad de las existencias en la selva, precipitan a la actualidad, el curso de la historia indígena, en contraste con la historia y racionalidad ilustrada. En términos warburgianos afirmamos entonces, que las fuerzas de los espíritus de la selva, poseen en sus formas, una vida evolutiva y situada, gracias al Nachleben. Para explicarlo de otro modo, utilizamos el ejemplo de las danzas rituales andinas mencionadas por Cornejo Polar, en ellas señala, no se evoca tanto el hecho histórico del encuentro hostil entre españoles e incas, sino como renovación simbólica que no prefigura ningún resultado, más bien otorga cierto cariz orgánico de multiformes estratos de significación, dejando entre paréntesis el registro escrito del desencuentro como de la memoria asociada a ello:

En los movimientos de la danza (...) la narración histórica de las crónicas, parece extraviarse, como disuelta en otra materia (no la escritura sino el ritmo de los cuerpos) y en otro espacio (no el privado que es propio de la escrituralectura sino el público de las calles y plazas). (...) a partir de otra racionalidad cultural, la linealidad, parcelación y finitud de la historia escrita al modo de Occidente carece de sentido. La historia que cuenta la comparsa no la falsifica: la sustituye por otra, diversa, que tiene su propia legitimidad hasta sus condicionantes formales distintivos. Para decirlo en grueso: no es lo mismo escribir la historia que bailarla (C. Polar, 2003, p. 46).

En su biología, las imágenes se comprometen con la memoria, conmemoración, ideación e imaginación poética. Dando cuenta de las formas vivientes de la naturaleza, las imágenes orales de Kopenawa, intentan apropiarse de un fenómeno natural en sus formas vivientes, para ello, en un principio gracias a la ingesta del yãkõanahi, el chamán se transforma en el causante del descenso de los espíritus, perdiendo su identidad apropiada por los utupë y seguido, baila tras mudar en xapiripë, agitando como ellos hojas de palmeras, exuberancia dionisíaca y reluciente sobre los finos caminos. Las imágenes también, bajo la supremacía de la conciencia Yanomami, amparan los discursos de varios sujetos más o menos explícitos en sus contenidos transculturales (misioneros, garimpos, madereros, funcionarios del gobierno y de organizaciones internacionales, investigadores, entre otros de "pensamiento cerrado") ${ }^{33}$.

\footnotetext{
33 “(...) El blanco, que no conoce nada del bosque, necesita ver y leer para recordar. Si hablo con usted, usted va a olvidar lo que dije. Pero con el libro [A Queda do Céu], usted va a seguir leyendo, al día siguiente va a leer de nuevo, y así (...) ¿Qué es la riqueza? Es comida: frutas, castañas, asaí. Los blancos también son hijos de la tierra, pero sin los indígenas en la selva todo va a ser peor, va a haber más lluvias, más cambios climáticos. Ya está sucediendo, se meten en nuestro territorio, contaminan nuestros ríos, matan nuestros peces. Yo confío en la fuerza de la naturaleza. Nosotros no vamos a matar ningún hombre blanco, la que lo va a matar es la naturaleza. Estoy luchando para defender mi pueblo para cuidar la tierra, defender la tierra para cuidar los saberes de mi pueblo (...) En los años 91,92, el Gobierno sacó 40 mil garimpeiros; después de eso todo se había calmado un poco, pero al tiempo volvieron, porque ya vieron oro. Hoy en 2020 están ahí. Están talando el 286 | AlPHA № 52 (JuLIO 2021) PÁGS. 271-289. ISSN 07 16-4254
} 
Para finalizar, se desprenden aquí dos elementos, a saber, la figura del chamán en el rol de un Yo-memorioso y la función doble de la oralidad, es decir, como práctica de colección o archivo y como manifestación de un tipo de imaginación amerindia cuya expresión indica cierta inmanencia de los símbolos o cierto psiquismo animado a partir de sus criaturas.

\section{IMPRESIONES}

En términos generales, hemos intentado en esta divagación, avanzar sobre la validación de las imágenes orales de Kopenawa como producto de una articulación entre procesos de subjetivación, de relacionamiento ecológico y principalmente de fuerzas emotivas productoras de formas y gestos. La memoria como técnica, las formas sensibles de la conmemoración, la imaginación poética, la complejidad del juego de transferencias y contratransferencias entre el chamán y la cultura, o entre lo extrahumano y el saber del chamán -buscando absorber los dictados del entorno, siempre cambiante, en sus formas vivientes-, configuran un tejido heterogéneo en el que se visibiliza, pese a la dificultad de la traducción del pensamiento amerindio a la razón ilustrada, el aquí y ahora de una experiencia en evidente e inevitable desajuste con el mundo contemporáneo, manifiesto en la articulación del discurso de Kopenawa. En él compiten múltiples sujetos, a nivel discursivo, anímico y político, la organicidad interna del relato, acoge necesidades étnicas colectivas y desde tiempos anteriores hasta hoy.

A su vez, sostenemos que el hombre amazónico posee un devenir acoplado a la multiplicidad y que su potencia diferencial de estados en los que un cuerpo efervesce, rebosa y está fuera de sus límites, promoviendo la personificación de los xapiri mediante la tactilidad y la motricidad, resultando su huella visual y estética en las fuerzas primarias ancestrales utupë, depositarias del archivo memorioso en el que las pulsiones de vida y muerte, de placer y rechazo sostienen cierta tensión con el mundo, en apertura a él o en repliegue. Son estas pulsiones las que permiten cierta evolución de las imágenes constitutivas del órgano retentivo y sabio yanomami; aquellos que han desaparecido, los animales ancestrales, padres de la naturaleza, humanos originales, aun cuando han sido sucedidos por presas, expresan la ética ancestral selvática y resisten la amenaza material y simbólica de la avanzada moderna. Refracciones, resonancias, vibraciones que restituyen al origen una presencia activa, el ideal hombre-mundo, yanomami.

Animais Ancestrais, vierte en las grabaciones de Brus Albert un ideal que no permite que la letra se superponga sobre la voz. Es más, la narración acerca de los

\footnotetext{
bosque, entran y salen, ellos están juntos con la policía federal, con las autoridades, hay empresarios, senadores, políticos. Están más fuertes que antes. Bolsonaro es un garimpeiro, su papá era garimpeiro, el presidente los está empujando para que crezca la minería. El propio presidente es un garimpeiro" (Kopenawa, 2020), en entrevista con Daniel Wizenberg, en el contexto de la exposición fotográfica sobre Kopenawa, por Claudia Andújar. Fundación Cartier de arte contemporáneo de París, 10 de mayo.
} 
animales ancestrales, excede a las palabras emitidas por el chamán gracias a los campos anímicos y conciencias históricas en el margen de la narración; invirtiendo incluso los roles de subordinación de indígenas y blancos, ante el mundo. El desdén de Kopenawa por la escritura no es semántico sino político, podemos entrever cómo el testimonio del líder espiritual y diplomático invierte el rol de la escritura en tanto forma de dominio y conquista para transformarla en "palabras que permiten ver", como ve un Yanomami. El éxito inicial del hombre blanco como primera derrota de los espíritus de la floresta, esta vez se revierte y la oralidad es el vehiculante de las formas vivas de un poder selvático actual.

\section{OBRAS CITADAS}

Austin, John L. (2018). Cómo hacer cosas con palabras. Mexico: Paidós.

Berque, Augustin (2009). El pensamiento paisajero. Madrid: Bilbioteca Nueva.

Cornejo Polar, Antonio (1978). "El indigenismo y las literaturas heterogéneas: su doble estatuto socio-cultural”. Revista de Crítica Literaria Latinoamericana 4/7-8: 7-21.

Deleuze, Gilles y Guattari, Félix (2015). Mil mesetas. Capitalismo y esquizofrenia. Valencia: Pre-Textos.

Descola, Phillipe (2016). La composición de los mundos. Buenos Aires: Capital Intelectual. (2005). Las lanzas del crepúsculo. México: Fondo de Cultura Económica.

Didi-Huberman, Georges (2018). La imagen superviviente. Madrid: ABADA.

Fumagalli, Armando (1996). "El Indice en la filosofía de Peirce". Anuario Filosófico. XXIX/3, 1127-1440.

Goddard, Jean-Christophe (2016). "Notas sobre A queda do céu de Davi Kopenawa e Bruce Albert por um leitor branco". Clima Com Cultura Científica: pesquisa, jornalismo e arte I Ano 3, $\mathrm{N}^{\circ} 5$.

Lestel, Dominique (2018). Hacer las paces con el animal. Santiago: Qual quelle.

Librandi-Rocha, Marília (2012). "Escutar a escrita: por uma teoria literária ameríndia". O eixo e a roda: v. 21, n. 2, 179-202.

Kopenawa, Davi y Bruce, Albert (2015). A queda do céu. Palavras de um xamä Yanomami. Sao Paulo: Companhia das letras.

(2013). The falling sky: words of a Yanomami Shaman. Cambridge: Belknap Press.

Severi, Carlo (2010). El Sendero y la Voz. Una antropología de la memoria. Buenos Aires: Sb.

Stolze Lima, Tânia (2015). Um peixe olhou pra mim. O povo Yudjá e a perspectiva. São Paulo: UNESP.

Survival International (2020). "Davi Kopenawa Yanomami Currículum Vitae - Líder y Chamán indígena amazónico". Disponible en: https://survivalinternational.org/ Rescatado el 26 de Marzo de 2020.

288 | AlPHA № 52 (JuLIO 2021) PÁGS. 271-289. ISSN 07 16-4254 
Viveiros de Castro, Eduardo (2009). Metafísicas canínbales. Buenos Aires: Katz.

— (2006). "A floresta de Cristal: Notas sobre a ontología dos espiritos amazónicos". Cadernos de campo, São Paulo, № 14/15, 1-382.

Wagner, Roy (1986). Symbols that stand for themselves. Chicago: University of Chicago Press.

Warburg, Aby (2005). Renacimiento del paganismo. Madrid: Alianza.

Wizenberg, Daniel (2020). "Cuando se va la naturaleza, atrás viene la pobreza". Entrevista al líder indígena del Amazonas Davi Kopenawa. Disponible en: https://www.pagina12.com.ar/246652-entrevista-al-lider-indigena-delamazonas-davi-kopenawa Rescatado el 20 de Marzo de 2020. 